Nama : Natasya Belina Gosal

NRP : 130218002

KP : A

\title{
The Uncertainty of Global Economy has Renewed Strategy in Indonesia
}

Currently, the uncertainty of global economic conditions makes every company in Ind onesia have to ad apt and change based on the principles of GCG (Good Corporate Governance) in an orderly manner to survive. Business people in Indonesia are required to always update, innovate and create diversification in order to survive in the midst of increasingly fierce business competition. This has made many companies try the latest management systems to deal with global economic disruptions in the hope that the company will be sustainable and adaptive to the times. Companies are trying to make changes, experiment with new business capital, transform business and human resources, and adapt to the 4.0 industrial revolution.

The industrial revolution requires every company to adapt to technology. During the Covid-19 pandemic, companies in Indonesia also made adjustments to technological developments, especially during the Industrial Revolution 4.0. Business challenges come from outside and inside the company, therefore the company must be prepared for changes. The existence of technology is very helpful in terms of business. Technology makes work easier, faster, more practical, effective and efficient. The trends of globalization, digitization, and trade wars expose businesses to volatility, uncertainty, complexity, and ambiguity (VUCA).

When companies are faced with difficult challenges and problems, transformation is needed. Business transformation is also needed in uncertain global economic conditions. Transformation can be done by changing the internal structure of the company and not violating business ethics and GCG principles, changes that can be made are aspects of strategy, systems, management, organization, information technology, human resources, and funding. Thus, selfassessment is needed so that the direction and alignment of the company's adjustment process, including employee competencies, can be identified and an agile organizational structure can carry out strategy with existing processes. 
Companies need to develop and build a GCG (Good Corporate Governance) system. GCG is basically a set of rules that governs managing and supervising the relationship between company managers and stakeholders in the company in an effort to increase the value and market valuation of the company. By implementing GCG, companies will get many benefits, such as ensuring a corporate culture, information disclosure, an effective audit system, and control risks that always refer to GCG standards. GCG is good if the company processes are carried out in a transparent manner, information disclosure, and has a good corporate culture. Companies in Indonesia have implemented GCG because it is a tool and guideline for companies, and can increase stakeholder trust. The transformation process must be able to fulfill the basic principles of GCG, transparency, accountability, responsiveness, independence and justice.

In addition to implementing GCG in business, companies must also pay attention to aspects of human resources. Employees are an important aspect of the company. Companies must be able to manage their human resources properly. In the development of the digital economy, many companies have created jobs, especially for human resources who have the ability to operate information technology, software programming experts. Company leaders must be able to adapt when facing the challenges of global economic uncertainty filled with volatility, uncertainty, complexity and ambiguity (VUCA). This is proven by the implementation of GCG in the company to be able to increase company value, market value, cultural value, information disclosure, effectiveness of audit systems, and risk control. Maximization benefits can be obtained if governance runs well and is always in line with compliance and conformity with ethics and norms.

Bank BNI is a company that has succeeded in changing its systems and resources in accordance with the principles of GCG. In the very tight competition in the banking business in Indonesia, Bank BNI has issued digital mobile banking products, digital loans, mobile money transfers, chat banking, and QR Code-based payments. Based on the results of research conducted by Tayibnapis and Wuryaningsih; Gora R. (2019) states that by implementing Good Corporate Governance it can help companies increase value, effectiveness, workforce productivity, and solve problems both internally and externally.

One of the implementation of GCG in companies in Indonesia is PT. Indonesia stock exchange. IDX as a capital market facilitator and regulator in Indonesia is committed to becoming a healthy and globally competitive Stock Exchange. The implementation of good GCG 
commitment or what is commonly known as Good Corporate Governance (GCG) is contained in the Company's mission, which is to create competitiveness to attract investors and issuers by empowering Exchange Members and Participants, creating added value, cost efficiency and implementing good governance. The benefits of implementing GCG can have a positive impact on the creation of corporate accountability, fair and independent transactions, as well as the reliability and improvement of the quality of information to the public.

IDX implements GCG with the aim of being a guideline for the Board of Commissioners in supervising and providing advice to the Board of Directors in managing the Company, as a guideline for the Board of Directors in carrying out daily activities. The Company is based on high moral values by observing the Articles of Association, business ethics, laws and other applicable laws and regulations, as well as a guideline for the management and employees of the IDX in carrying out daily activities and tasks in accordance with the principles of GCG. The IDX also carries out several strategies so that the implementation of GCG can run well, such as the IDX regularly reviews the Guidelines, Charter and Procedures. This aims to improve the quality of the Guidelines, Charter and Procedures so that the IDX can produce better performance. The IDX also continues to carry out the socialization process related to these GCG principles to all employees and stakeholders with the aim of instilling GCG principles in all employees, so that in carrying out the Company's operational activities, employees always comply with GCG regulations.

\section{Reference}

Wuryaningsih, A. Z., \& Gora, R. (2019). Companies in Indonesia in the vortex of global economic disruption. Education and Humanities Research 